\title{
Is hypertriglyceridemia a prognostic factor in sepsis?
}

This article was published in the following Dove Press journal:

Therapeutics and Clinical Risk Management

27 February 2014

Number of times this article has been viewed

\author{
Ali Cetinkaya' \\ Abdulsamet Erden' \\ Deniz Avci' \\ Hatice Karagoz' \\ Samet Karahan' \\ Mustafa Basak' \\ Kadir Bulut ${ }^{\prime}$ \\ Vedat Gencer' \\ Hasan Mutlu² \\ 'Internal Medicine Department, \\ Kayseri Training and Research \\ Hospital, Kayseri, Turkey; ${ }^{2}$ Medical \\ Oncology Department, Acıbadem \\ Kayseri Hospital, Kayseri, Turkey
}

Correspondence: Samet Karahan Kayseri Training and Research Hospital, Internal Medicine Department, Kayseri Eğitim Araștırma Hastanesi, İç Hastalıkları Kliniği, 9. Blok 3. Kat Kocasinan, Kayseri, Turkey

Tel +905063020036

Email doktorsamet@yahoo.com
Introduction: Sepsis and septic shock are important causes of mortality in intensive care unit patients, hence early diagnosis and therapy are important in management of their treatment. The available information on sepsis patients is not enough to recommend or to discard the routine evaluation of triglyceride (TG) levels at the onset of sepsis. The aim of this study was to investigate the association of hypertriglyceridemia and clinical outcome (or mortality) in patients with severe sepsis.

Materials and methods: Between January 1 and December 31, 2011, a total of 84 patients with sepsis from the intensive internal care unit at the Kayseri Training and Research Hospital, Kayseri, Turkey, were investigated retrospectively. Sepsis was defined according to the American College of Chest Physicians/Society of Critical Care Medicine/European Society of Intensive Care Medicine consensus conference definitions. For each patient, survival was recorded at the end of the last day of hospitalization as dead or alive. The TG values were taken retrospectively from the records, which were performed routinely for each patient with sepsis at the time of diagnosis. TG $>150 \mathrm{mg} / \mathrm{dL}$ was considered as hypertriglyceridemia.

Results: The percentages of male and female patients were $44 \%$ and $56 \%$, respectively. The mean age of patients was $71.49 \pm 11.071$ years. The percentage of patients with TG values more than $150 \mathrm{mg} / \mathrm{dL}$ was $81 \%(25 / 31)$ in the non-survivor group and $19 \%(6 / 31)$ in the survivor group. There was a significant difference regarding TG values between groups $(P=0.039)$.

Discussion: It was observed in this study that patients in the intensive care unit with sepsis had high TG levels. We also observed that the TG level $>150 \mathrm{mg} / \mathrm{dL}$ at 0 hour (onset of sepsis) was a significant predictive marker of sepsis mortality rate. The contribution of hypertriglyceridemia to mortality might be modest compared to increase in severity of illness, but, nevertheless, these simple measurements represent a potential therapeutic target in sepsis.

Keywords: triglyceride, prognosis, mortality, sepsis

\section{Introduction}

Sepsis and septic shock are important causes of mortality ${ }^{1}$ in intensive care unit patients, hence early diagnosis and therapy are important in management of their treatment. Sepsis is defined as the association of a number of nonspecific inflammatory responses with evidence, or suspicion, of a microbial origin. ${ }^{2,3}$ The signs and symptoms of sepsis are highly variable. Symptoms are nonspecific but present a picture of systemic illness. Lipopolysaccharide, which is released from the outer membrane of Gramnegative bacteria, plays a key role in initiating the inflammatory response in sepsis. Hypertriglyceridemia is commonly observed in patients with Gram-negative infections and animals administered live Gram-negative bacteria or endotoxin. ${ }^{4}$ In one study, the elevation in plasma triglyceride (TG) level observed 24 hours after Escherichia coli 
infusion was attributed to a reduction in TG clearance rates rather than an increase in liver secretion. ${ }^{5}$ Increased plasma TG concentrations can result from an increased rate of verylow-density lipoprotein (VLDL) secretion from the liver, from a decreased rate of removal of VLDL and TG, or from a combination of changes in both processes. Many of the sepsis-induced disturbances in lipid metabolism are thought to be cytokine related. Tumor necrosis factor (TNF)- $\alpha$ has been shown to elevate serum TG level by increasing the hepatic production ${ }^{6,7}$ and also decreasing lipoprotein lipase (LPL) activity in adipose tissue. ${ }^{8,9}$ The available information on sepsis patients is not enough to recommend or to discard the routine evaluation of TG levels at the onset of sepsis. The aim of this study was to investigate the association of hypertriglyceridemia and clinical outcome (or mortality) in patients with severe sepsis.

\section{Materials and methods}

Between January 1 and December 31, 2011, a total of 84 patients with sepsis from the intensive internal care unit at the Kayseri Training and Research Hospital, Kayseri, Turkey, were investigated retrospectively, using hospital records. Medical history was recorded from each patient's chart, including age, sex, and chronic background illnesses (ischemic heart disease, diabetes mellitus, hypertension, malignancy, renal failure). Blood pressure, heart rate, and body temperature were recorded for each patient. Laboratory data included: complete blood count; urea; creatinine; glucose; calcium; sodium; potassium; phosphate; uric acid; liver function tests; albumin; and a lipid profile (total cholesterol, calculated serum high-density lipoprotein cholesterol, and TG). Sepsis was defined according to the American College of Chest Physicians/Society of Critical Care Medicine/European Society of Intensive Care Medicine consensus conference definitions. The patients included in this study were on broad-spectrum antibiotics and were not taking lipid-lowering drugs. Patients who received enteral or parenteral nutrition within 8 hours before the diagnosis of sepsis were excluded.Those with a history of chronic renal failure, diabetes mellitus, ischemic heart disease, hypertension, or hyperlipidemia were excluded. For each patient, survival was recorded at the end of the last day of hospitalization as dead or alive. The TG values were taken retrospectively from the records, which were performed routinely for each patient with sepsis at the time of diagnosis. At our institution's laboratory, the upper limit for serum TG value is $149 \mathrm{mg} / \mathrm{dL}$. In general, serum TG concentration levels less than $150 \mathrm{mg} / \mathrm{dL}$ (less than $1.7 \mathrm{mmol} / \mathrm{L}$ ) are accepted as normal; 150 to $199 \mathrm{mg} / \mathrm{dL}$ (1.7 to $2.2 \mathrm{mmol} / \mathrm{L}$ ) as close to high; 200 to $499 \mathrm{mg} / \mathrm{dL}$ (2.3 to $5.6 \mathrm{mmol} / \mathrm{L}$ ) as high; and greater than $500 \mathrm{mg} / \mathrm{dL}(5.7 \mathrm{mmol} / \mathrm{L})$ as very high. ${ }^{10}$ Thus, before data analysis, hypertriglyceridemia was defined as any $\mathrm{TG}$ level $\geq 150 \mathrm{mg} / \mathrm{dL}$.

\section{Statistical analysis}

For statistical analysis, the Statistical Package for the Social Sciences ([SPSS] v 16; IBM Corporation, Armonk, NY, USA) was used. Continuous variables were tested for normal distribution by the Kolmogorov-Smirnov test. We reported continuous data as mean and standard deviation. Categorical variables were summarized as percentages and compared with the chi-square test. The chi-square test was used to evaluate the relationship between TG levels and mortality. $P$-values $<0.05$ were considered significant. To evaluate the relationship between biochemical parameters and mortality, independent samples $t$-test was used. In addition, mean and frequency analysis were used.

\section{Results}

The percentages of male and female patients were $44 \%$ and $56 \%$, respectively. The mean age of patients was $71.49 \pm 11.071$ years. Considering the patients as survivors or non-survivors, the mean age of patients was $68.19 \pm 13.88$ years in the survivor group and $72.97 \pm 9.31$ years in the non-survivor group $(P=0.019)$. When biochemical parameters were evaluated, no significant difference was found between survivor and non-survivor groups. The mean TG level of patients was $122.96 \pm 65.01 \mathrm{mg} / \mathrm{dL}$ in the survivor group and $167.42 \pm 109.58 \mathrm{mg} / \mathrm{dL}$ in the non-survivor group $(P=0.083)$. The relationship of biochemical parameters and mortality in patients with sepsis is given in Table 1. TG $>150 \mathrm{mg} / \mathrm{dL}$ was considered as hypertriglyceridemia. The percentage of patients with TG values more than $150 \mathrm{mg} / \mathrm{dL}$ was $81 \%(25 / 31)$ in the non-survivor group and $19 \%(6 / 31)$ in the survivor group. For the TG values, there was a significant difference between the two groups $(P=0.039)$. Values for each group are given in Table 2. The risk of mortality in the group of patients with high TG levels was $81 \%$, compared to $58 \%$ in the group with normal TG levels. The odds for mortality were $4.1(25 / 6)$ and $1.4(28 / 20)$, respectively. We calculated and added the risk ratio $(0.806 / 0.583=1.382)$ and the odds ratio $(4.1 / 1.4=2.928)$.

\section{Discussion}

In this study, it was observed that patients in the intensive care unit with sepsis had high TG levels. Lipoproteins have been known to play a role in innate immunity and variations 
Table I The relationships between biochemical parameters and mortality in patients with sepsis

\begin{tabular}{|c|c|c|c|}
\hline Parameter & $\mathbf{N}$ & $\begin{array}{l}\text { Mean } \pm \text { standard } \\
\text { deviation }\end{array}$ & $P$-value \\
\hline Age, years & & & 0.019 \\
\hline Non-survivor & 58 & $72.97 \pm 9.31$ & \\
\hline Survivor & 26 & $68.19 \pm 13.88$ & \\
\hline Glucose, mg/dL & & & 0.483 \\
\hline Non-survivor & 58 & |47.78 \pm 99.78 & \\
\hline Survivor & 26 & $145.58 \pm 89.12$ & \\
\hline Blood urea nitrogen, $\mathrm{mg} / \mathrm{dL}$ & & & 0.709 \\
\hline Non-survivor & 58 & $65.87 \pm 36.51$ & \\
\hline Survivor & 26 & $48.58 \pm 37.69$ & \\
\hline Creatine, $\mathrm{mg} / \mathrm{dL}$ & & & 0.765 \\
\hline Non-survivor & 58 & $3.40 \pm 2.35$ & \\
\hline Survivor & 26 & $2.11 \pm 2.59$ & \\
\hline Aspartate, IU/L & & & 0.054 \\
\hline Non-survivor & 58 & $96.91 \pm 221.27$ & \\
\hline Survivor & 25 & $47.80 \pm 49.05$ & \\
\hline Aspartate, IU/L & & & 0.302 \\
\hline Non-survivor & 58 & $67.69 \pm|69.8|$ & \\
\hline Survivor & 25 & $47.08 \pm 77.07$ & \\
\hline Alkaline phosphatase, IU/L & & & $0.07 \mid$ \\
\hline Non-survivor & 52 & $115.88 \pm 73.58$ & \\
\hline Survivor & 25 & $|4| .44 \pm 101.21$ & \\
\hline Sodium, $\mathrm{mmol} / \mathrm{L}$ & & & 0.288 \\
\hline Non-survivor & 58 & $|40.34 \pm| \mid .60$ & \\
\hline Survivor & 25 & $138.00 \pm 7.46$ & \\
\hline Potassium, $\mathrm{mmol} / \mathrm{L}$ & & & 0.391 \\
\hline Non-survivor & 57 & $4.46 \pm 0.86$ & \\
\hline Survivor & 24 & $4.49 \pm 1.30$ & \\
\hline Triglycerides, mg/dL & & & 0.083 \\
\hline Non-survivor & 53 & $167.42 \pm 109.58$ & \\
\hline Survivor & 26 & $|22.96 \pm 65.0|$ & \\
\hline
\end{tabular}

in their levels have been observed in a variety of inflammatory disorders, but not much is known about lipoprotein metabolism in patients with sepsis. Elevated plasma TG level may result either from a decreased rate of peripheral removal or an increased rate of production and secretion of liver. Previous data, showing a reduction in LPL activity in peripheral tissues of Gram-negative septic rats ${ }^{11-13}$ and septic patients, ${ }^{14}$ suggest a defect in the clearance of TG as one of the factors involved in the cause of hypertriglyceridemia. The observed decrease in tissue LPL activity in rats administered live $E$. coli was also expected, since postheparin plasma lipase

Table 2 The relationship between triglyceride levels and mortality in patients with sepsis

\begin{tabular}{llll}
\hline $\begin{array}{l}\text { Triglyceride level, } \\
\mathbf{m g} / \mathbf{d L}\end{array}$ & $\begin{array}{l}\text { Non-survivor, } \\
\mathbf{n}(\%)\end{array}$ & $\begin{array}{l}\text { Survivor, } \\
\mathbf{n}(\%)\end{array}$ & P-value \\
\hline Triglycerides $>150$ & $25(8 \mathrm{I})$ & $6(19)$ & 0.039 \\
Triglycerides $<150$ & $28(58)$ & $20(42)$ & \\
\hline
\end{tabular}

activity and adipose tissue LPL activity have been reported to be decreased in bacteremic monkeys and rats, respectively. ${ }^{15,16}$ Concomitant with the reduced enzyme activities, circulating TG concentrations were increased. The initial rise in serum TG level in the E. coli-treated rats may have been mediated by the increased concentrations of plasma catecholamines and glucocorticoids, which are also elevated in rat models of endotoxemia, ${ }^{17,18}$ polymicrobial sepsis, ${ }^{19}$ and E. coli bacteremia. ${ }^{20}$ Recently, catecholamines have been shown to mediate endotoxin-induced hypertriglyceridemia, may contribute to the downregulation of adipose LPL. ${ }^{21}$ Epinephrine has also been shown to lower LPL activity in adipocytes by way of decreasing LPL synthesis. ${ }^{22}$ Cytokines such as TNF- $\alpha$ and the interleukins may mediate the hypertriglyceridemia associated with sepsis and endotoxemia..$^{23} \mathrm{~A}$ study on endotoxin-injected rats with suppressed LPL tissue activities showed that the hypertriglyceridemia was the result of a reduction in the clearance rate of TG from the plasma. ${ }^{24}$ Endotoxemia ${ }^{25}$ and polymicrobial sepsis ${ }^{26}$ have also been shown to have produced an elevation in serum TNF- $\alpha$ at the 60th minute. TNF administration was shown to produce a rapid rise in serum $\mathrm{TG}$ level between the 45th and 90th minutes, which was due to an increase in hepatic TG synthesis and VLDL secretion. ${ }^{27,28}$ Other cytokines, such as interferons, the interleukins, and platelet-activating factor, may also have a role in altering lipid metabolism after E. coli sepsis..$^{29,30}$ One study showed that the hypertriglyceridemia of sepsis may have a protective function. ${ }^{31}$ Lipoproteins bind endotoxin, thus preventing their interaction with lipopolysaccharide-binding protein and, subsequently, their uptake by macrophages that triggers the release of the inflammatory mediators. ${ }^{31}$ We have also observed that the TG level $>150 \mathrm{mg} / \mathrm{dL}$ at 0 hour (onset of sepsis) was a significant predictive marker of sepsis mortality rate, and hypertriglyceridemia can be defined as a risk factor for mortality in patients with sepsis.

The contribution of hypertriglyceridemia to mortality might be modest compared to increase in severity of illness, but, nevertheless, these simple measurements represent a potential therapeutic target in sepsis. The mechanism that modifies TG level in sepsis is not yet well understood, and further studies in larger populations with sequential cholesterol monitoring for a longer period will lead to more timely interventions and enhance patient outcomes.

\section{Conclusion}

According to our results, the routine measurement of serum TGs at the onset of sepsis and sequential monitoring are recommended. The measurement of TG can be a good 
predictor of hospital death in sepsis ; however, from the observations of the present study, we suggest that new therapies directed at decreasing serum TG levels may offer important alternative options for better management of sepsis.

\section{Disclosure}

The authors have no conflicts of interest to report in this work.

\section{References}

1. Rangel-Frausto MS, Pittet D, Costigan M, Hwang T, Davis CS, Wenzel RP. The natural history of the systemic inflammatory response syndrome (SIRS). A prospective study. JAMA. 1995;273:117-123.

2. [No authors listed]. American College of Chest Physicians/Society of Critical Care Medicine Consensus Conference: definitions for sepsis and organ failure and guidelines for the use of innovative therapies in sepsis. Crit Care Med. 1992;20:864-874.

3. Levy MM, Fink MP, Marshall JC, et al; SCCM/ESICM/ACCP/ATS/SIS. $2001 \mathrm{SCCM} / \mathrm{ESICM} / \mathrm{ACCP} / \mathrm{ATS} /$ SIS International Sepsis Definitions Conference. Crit Care Med. 2003;31:1250-1256.

4. Scholl RA, Lang CH, Bagby GJ. Hypertriglyceridemia and its relation to tissue lipoprotein lipase activity in endotoxemic, Escherichia coli bacteremic, and polymicrobial septic rats. J Surg Res. 1984;37(5):394-401.

5. Lanza-Jacoby S, Tabares A. Triglyceride kinetics, tissue lipoprotein lipase, and liver lipogenesis in septic rats. Am J Physiol. 1990; 258(4 Pt 1):E678-E685.

6. Feingold KR, Staprans I, Memon RA, et al. Endotoxin rapidly induces changes in lipid metabolism that produce hypertriglyceridemia: low doses stimulate hepatic triglyceride production while high doses inhibit clearance. J Lipid Res. 1992;33(12):1765-1776.

7. Feingold KR, Grunfeld C. Tumor necrosis factor-alpha stimulates hepatic lipogenesis in the rat in vivo. J Clin Invest. 1987;80(1):184-190.

8. Grunfeld C, Gulli R, Moser AH, Gavin LA, Feingold KR. Effect of tumor necrosis factor administration in vivo on lipoprotein lipase activity in various tissues of the rat. J Lipid Res. 1989;30(4):579-585.

9. Semb H, Peterson J, Tavernier J, Olivecrona T. Multiple effects of tumor necrosis factor on lipoprotein lipase in vivo. J Biol Chem. 1987;262(17): 8390-8394.

10. National Cholesterol Education Program (NCEP) Expert Panel on Detection, Evaluation, and Treatment of High Blood Cholesterol in Adults (Adult Treatment Panel III). Third Report of the National Cholesterol Education Program (NCEP) Expert Panel on Detection, Evaluation, and Treatment of High Blood Cholesterol in Adults (Adult Treatment Panel III) final report. Circulation. 2002;106: 3143-3421.

11. Bagby GJ, Spitzer JA. Lipoprotein lipase activity in rat heart and adipose tissue during endotoxic shock. Am J Physiol. 1980;238(3): H325-H330.

12. Bagby GJ, Spitzer JA. Decreased myocardial extracellular and muscle lipoprotein lipase activities in endotoxin-treated rats. Proc Soc Exp Biol Med. 1981;168(3):395-398.

13. Lanza-Jacoby S, Tabares A, Sitren HS, Kosar E. Comparison of glucose and glucose plus lipid as caloric sources in parenterally fed rats. $A m J$ Physiol. 1987;253(2 Pt 1):E158-E164.
14. Robin AP, Greenwood MR, Askanazi J, Elwyn DH, Kinney JM. Influence of total parenteral nutrition on tissue lipoprotein lipase activity during chronic and acute illness. Ann Surg. 1981;194(6):681-686.

15. Kaufmann RL, Matson CF, Rowberg AH, Beisel WR. Defective lipid disposal mechanisms during bacterial infection in rhesus monkeys. Metabolism. 1976;25(6):615-624.

16. Lanza-Jacoby S, Lansey SC, Cleary MP, Rosato FE. Alterations in lipogenic enzymes and lipoprotein lipase activity during gram-negative sepsis in the rat. Arch Surg. 1982;117(2):144-147.

17. McKechnie K, Dean HG, Furman BL, Parratt JR. Plasma catecholamines during endotoxin infusion in conscious unrestrained rats: effects of adrenal demedullation and/or guanethidine treatment. Circ Shock. 1985;17(1):85-94.

18. Givalois L, Dornand J, Mekaouche M, et al. Temporal cascade of plasma level surges in $\mathrm{ACTH}$, corticosterone, and cytokines in endotoxinchallenged rats. Am J Physiol. 1994;267:R164-R170.

19. Hahn PY, Wang P, Tait SM, Ba ZF, Reich SS, Chaudry IH. Sustained elevation in circulating catecholamine levels during polymicrobial sepsis. Shock. 1995;4(4):269-273.

20. Jones SB, Westfall MV, Sayeed MM. Plasma catecholamines during E. coli bacteremia in conscious rats. Am J Physiol. 1988;254(3 Pt 2): R470-R477.

21. Nonogaki K, Moser AH, Feingold KR, Grunfeld C. Alpha-adrenergic receptors mediate the hypertriglyceridemia induced by endotoxin, but not tumor necrosis factor, in rats. Endocrinology. 1994;135(6):2644-2650.

22. Ong JM, Saffari B, Simsolo RB, Kern PA. Epinephrine inhibits lipoprotein lipase gene expression in rat adipocytes through multiple steps in posttranscriptional processing. Mol Endocrinol. 1992;6(1):61-69.

23. Beutler B, Cerami A. Cachectin and tumour necrosis factor as two sides of the same biological coin. Nature. 1986;320(6063):584-588.

24. Bagby GJ, Corll CB, Martinez RR. Triacylglycerol kinetics in endotoxic rats with suppressed lipoprotein lipase activity. Am J Physiol. 1987;253(1 Pt 1):E59-E64.

25. Cannon JG, Tompkins RG, Gelfand JA, et al. Circulating interleukin-1 and tumor necrosis factor in septic shock and experimental endotoxin fever. J Infect Dis. 1990;161(1):79-84.

26. Ayala A, Perrin MM, Kisala JM, Ertel W, Chaudry IH. Polymicrobial sepsis selectively activates peritoneal but not alveolar macrophages to release inflammatory mediators (interleukins- 1 and -6 and tumor necrosis factor). Circ Shock. 1992;36(3):191-199.

27. Tracey KJ, Fong Y, Hesse DG, et al. Anti-cachectin/TNF monoclonal antibodies prevent septic shock during lethal bacteraemia. Nature. 1987;330(6149):662-664.

28. Chajek-Shaul T, Friedman G, Stein O, Shiloni E, Etienne J, Stein Y. Mechanism of the hypertriglyceridemia induced by tumor necrosis factor administration to rats. Biochim Biophys Acta. 1989;1001(3):316-324.

29. Martich GD, Danner RL, Ceska M, Suffredini AF. Detection of interleukin 8 and tumor necrosis factor in normal humans after intravenous endotoxin: the effect of antiinflammatory agents. $J$ Exp Med. 1991;173(4):1021-1024.

30. Evans RD, Ilic V, Williamson DH. Metabolic effects of plateletactivating factor in rats in vivo. Stimulation of hepatic glycogenolysis and lipogenesis. Biochem J. 1990;269(1):269-272.

31. Harris HW, Grunfeld C, Feingold KR, Rapp JH. Human very low density lipoproteins and chylomicrons can protect against endotoxin-induced death in mice. J Clin Invest. 1990;86(3):696-702.
Therapeutics and Clinical Risk Management

\section{Publish your work in this journal}

Therapeutics and Clinical Risk Management is an international, peerreviewed journal of clinical therapeutics and risk management, focusing on concise rapid reporting of clinical studies in all therapeutic areas, outcomes, safety, and programs for the effective, safe, and sustained use of medicines. This journal is indexed on PubMed Central, CAS,

\section{Dovepress}

EMBase, Scopus and the Elsevier Bibliographic databases. The manuscript management system is completely online and includes a very quick and fair peer-review system, which is all easy to use. Visit http://www.dovepress.com/testimonials.php to read real quotes from published authors. 